Vol 1 Issue 2, Oktober 2019, Page. 12-22

ISSN (print): 2622-5859 ISSN (online):2622-0881

DOI: $10.31605 /$ jcis.v2i1

\title{
Clustering Wilayah berdasarkan Data Kesehatan Lingkungan menggunakan Fuzzy C-Means
}

\author{
Siti Aminah*1, Irfan AP², Nuralamsah Zulkarnaim ${ }^{3}$ \\ ${ }^{123}$ Program Studi Teknik Informatika, Universitas Sulawesi Barat \\ Email: ${ }^{* 1}$ Aminahsiti114@gmail.com, ${ }^{2}$ irfan_ap@unsulbar.ac.id, ${ }^{3}$ nuralamsah@unsulbar.ac.id
}

\begin{abstract}
Abstrak
Kesehatan merupakan hal penting dalam kehidupan, karena dengan kesehatan kita dapat menjalankan kegiatan kita sehari - hari. Secara administratif, Kabupaten Majene terdiri dari 8 kecamatan, 82 desa/kelurahan dan 361 SLS (Satuan Lingkungan Setempat) yang terbagi dalam 257 dusun dan 104 lingkungan. Karena hal itu, kesehatan lingkungan pemukiman sangatlah penting. Tujuan utama dalam penelitian ini adalah mengelompokan tiap wilayah (kecamatan) menjadi beberapa kelompok dan mengetahui tingkat kesehatan lingkungan berdasarkan 5 parameter yang spesifik dengan menggunakan metode Fuzzy C-Means. Dengan adanya metode ini, keakurasian data dan tingkat kesehatan lingkungan menjadi lebih akurat. Hasil output dalam penelitian ini berupa informasi pengelompokan kesehatan lingkungan yang diharapkan mampu untuk menjadi bahan pertimbangan dalam menentukan tingkat kesehatan lingkungan berdasarkan 5 parameter yang menjadi indikator penyehatan lingkungan.
\end{abstract}

Kata kunci - Clustering, Fuzzy C-Means, Data Mining, Kesehatan Lingkungan

\begin{abstract}
Health is an important thing in life, because with health we can carry out our daily activities. Administratively, Majene Regency consists of 8 sub-districts, 82 villages / kelurahan and 361 SLS (Local Environmental Unit) which is divided into 257 hamlets and 104 neighborhoods. Because of that the environmental health of the settlement is very important. The main objective in this study is to group each region (sub-district) into several groups and determine the level of environmental health based on 5 specific parameters using the Fuzzy C-Means method, because with this method the accuracy of the data and the level of environmental health become more accurate. The output results in this study are information on the grouping of environmental health which is expected to be considered in determining the level of environmental health based on 5 parameters that are indicators of environmental health.
\end{abstract}

Keywords - Clustering, Fuzzy C-Means, Data Mining, Environmental Health

\section{PENDAHULUAN}

Peraturan Pemerintah Nomor 66 Tahun 2014 tentang Kesehatan Lingkungan menyatakan bahwa kesehatan lingkungan adalah upaya pencegahan penyakit dan/atau gangguan kesehatan dari faktor risiko lingkungan untuk mewujudkan kualitas lingkungan yang sehat baik dari aspek fisik, kimia, biologi, maupun sosial. Sedangkan menurut WHO, kesehatan lingkungan meliputi seluruh faktor fisik, kimia, dan biologi dari luar tubuh manusia dan segala faktor yang dapat mempengaruhi perilaku manusia. Kondisi dan control dari kesehatan lingkungan berpotensial untuk mempengaruhi kesehatan [1]. 
Clustering wilayah lingkungan sehat merupakan salah satu bentuk pengendalian yang sangat berguna agar program penyehatan lingkungan berupa : Penyehatan air dan sanitasi dasar, penyehatan permukiman dan tempat-tempat umum, penyehatan kawasan dan sanitasi darurat, serta pengelolahan air limbah (SPAL) dan tempat pembuangan sampah di suatu daerah tepat sasaran.

Clustering wilayah dilakukan untuk mengetahui tingkat kesehatan lingkungan yang ada di wilayah khususnya kabupaten Majene. Di kutip dari Badan Pusat Statistik Kabupaten Majene terdiri dari 8 kecamatan, 82 desa/kelurahan dan 361 SLS (Satuan Lingkungan Setempat) yang terbagi dalam 257 dusun dan 104 lingkungan. Selama ini dalam pengelompokan data indikator penyehatan lingkungan masih berbasis teknik komputasi manual, dimana perhitungannya masih memiliki sejumlah permasalahan khususnya dalam bidang konsistensi data. Dalam hal peningkatan pelayanan kesehatan Dinas Kesehatan Kabupaten Majene pada bidang kesehatan lingkungan maka dibutuhkan suatu sistem yang melakukan pengelompokan wilayah sehat berdasarkan pada data kesehatan lingkungan, sehingga penyuluhan, pelayanan, serta pemberian bantuan dapat lebih akurat dan tepat sasaran.

Salah satu algoritma dalam clustering adalah Fuzzy C-Means (FCM). adalah Fuzzy C-Means $(F C M)$ suatu teknik pengklusteran data yang mana keberadaan tiap - tiap titik data dalam suatu cluster ditentukan oleh derajat keanggotaan. Konsep dasar FCM, pertama kali adalah menentukan pusat cluster, yang akan menandai lokasi rata-rata untuk tiap-tiap cluster. Pada kondisi awal, pusat cluster ini masih belum akurat. Tiap-tiap titik data memiliki derajat keanggotaan untuk tiap-tiap cluster. Dengan cara memperbaiki pusat cluster dan derajat keanggotaan tiap-tiap titik data secara berulang, maka akan dapat dilihat bahwa pusat cluster akan bergerak menuju lokasi yang tepat. Perulangan ini didasarkan pada minimisasi fungsi objektif yang menggambarkan jarak dari titik data yang diberikan ke pusat cluster yang terbobot oleh derajat keanggotaan titik data tersebut.

Metode Fuzzy C-Means dipilih kerena berdasarkan penelitian sebelumnya yang membahas mengenai perbandingan antara metode K-Means dan Fuzzy C-Means dalam melakukan pengklusteran metode Fuzzy C-Means lebih unggul karena cluster yang dihasilkan lebih mendekatai ketepatan (valid) dan kualitas cluster yang lebih baik[2][3]. Tujuan utama dalam penelitian ini adalah mengelompokan tiap wilayah (kecamatan) menjadi beberapa kelompok dan mengetahui tingkat kesehatan lingkungan berdasarkan 5 parameter yang spesifik dengan menggunakan metode Fuzzy C-Means, karena dengan adanya metode ini keakurasian data dan tingkat kesehatan lingkungan menjadi lebih akurat.

\section{TINJAUAN PUSTAKA}

\subsection{Penelitian Terkait}

Dalam pemetaan wilayah lingkungan sehat. Dalam peneliian sebelumnya terdapat jurnal yang diteliti oleh Mukidin yang berjudul "Clustering Tingkat Kesehatan Lingkungan Berdasarkan Data Penyehatan Lingkungan Pemukiman Menggunakan Metode Fuzzy C-Means" [4], didapatkan hasil informasi penegelompokan kecamatan berdasarkan kemiripan nilai indikator penyehatan lingkungan pemukiman, infomasi masih ada beberapa kelemahan terutama terkait kriteria yang digunakan dalam mengolah data penyehatan lingkungan masih kurang sehingga hasil informasi yang masih kurang akurat mengingat masih terdapat kriteria pendukung yang dapat digunakan namun tidak digunakan. Amanda Putri Pertiwi dan Robert Kurniawan dengan judul penelitian "Pengelompokan Daerah Rawan Bencana Banjir Indonesia Tahun 2013 menggunakan Fuzzy C-Means" [5] mendapatkan hasil analisis cluster yang membentuk 3 kelompok cluster dari 4 variabel yang digunakan dengan metode Fuzzy C-Means dapat mempermudah melakukan untuk menganalisis daerah yang rawan Banjir. Alvian Kusuma Wijaya yang berjudul “ Implementasi Data Mining dengan Algoritma Fuzzy CMeans Studi Kasus Penjualan di UD Subur Baru“ [6], dijelaskan bahwa metode Fuzzy C-Means dapat mempermudah UD Subur Baru untuk mengidentifikasi tingkat penjualan produk berdasarkan tiga tingkatan yaitu sangat laku, laku dan kurang laku. Selain itu dilihat dari penelitian yang lain yang diteliti oleh Hanifa Setianingrum yang berjudul "Model Pemetaan Evaluasi Penilaian Kualifikasi Lulusan Berbasis Metode Fuzzy C-Means Clustering" [7] dijelaskan bahwa metode 
Fuzzy C-Means dapat mempermudah menentukan cara pembelajaran kepada mahasiswa dengan mengidentifikasi kualifikasi kelulusan dengan standar SKKNI.

Dalam penelitian internasional pada jurnal yang diteliti oleh Martin J. Bunch, T.Vasantha Kumara, R.Joseph yang berjudul Using Geographic Information System (GIS) For Spatial Planning and Environmental Management in India; Critical Considerations [8], dijelaskan bahwa penggunaan GIS di program penelitian pengelolaan lingkungan hidup di Sungai Cooum di Chennai yang berperan untuk perencanaan pengelolaan lingkungan hidup. Selain itu dapat dilihat dari Implementation Of The Fuzzy C-Means Clustering Algorithm, Meteorologi Data [9], dijelaskan bahwa Perhitungan metode Fuzzy C-Means yang dibandingkan perhitungan dengan metode $\mathrm{K}$ Means yang lebih cepat digunakan untuk menghitung dan dengan kesalahan yang minimum.

\subsection{Kesehatan Lingkungan}

Kesehatan Lingkungan menyatakan bahwa kesehatan lingkungan adalah upaya pencegahan penyakit dan/atau gangguan kesehatan dari faktor resiko lingkungan untuk mewujudkan kualitas lingkungan yang sehat baik dari aspek fisik, kimia, biologi, maupun sosial. Sedangkan menurut WHO, kesehatan lingkungan meliputi seluruh faktor fisik, kimia, dan biologi dari luar tubuh manusia dan segala faktor yang dapat mempengaruhi perilaku manusia. Kondisi dan control dari kesehatan lingkungan berpotensial untuk mempengaruhi kesehatan [1].

\subsection{Data Mining}

Data Mining Merupakan proses yang menggunakan teknik statistik, perhitungan, kecerdasan buatan dan machine learning untuk mengekstrasi dan mengidentifikasi informasi yang bermanfaat dan pengetahuan yang terkait dari berbagai basis data besar. Dalam data mining terdapat sebuah metode yang di gunakan untuk mengcluster data salah satunya yaitu, metode Fuzzy C-Means [10].

\subsection{Fuzzy C-Means}

Fuzzy C-Means (FCM) merupakan salah satu algoritma Fuzzy Clustering. Fuzzy C-Means (FCM) adalah suatu tenik pengklusteran data yang keberadaan setiap titik data dalam suatu cluster di tentukan oleh derajat keanggotaan. Teknik ini pertama kali di perkenalkan oleh Jim Bezdek pada tahu 1981. Output dari FCM bukan merupakan Fuzzy inference system, namun merupakan deretan pusat clusster dan beberapa derajat keanggotaan untuk tiap-tiap titik data. Informasi ini dapat digunakan untuk membangun suatu Fuzzy inference system. Kelebihan metode Fuzzy C-Means adalah penempatan pusat cluster yang tepat dibandingkan dengan metode cluster yang lain algoritma dari Fuzzy C-Means adalah sebagai berikut [11].

1. Menginput data yang akan dikelompokan, yaitu $X$ berupa matriks berukuran $\mathrm{n} \times \mathrm{m}(\mathrm{n}=$ jumlah sampel data, $\mathrm{m}=$ atribut setiap data). Xij data sampel ke-i $(\mathrm{i}=1,2, \ldots, \mathrm{n})$, atribut ke-j $(\mathrm{j}=1,2, \ldots, \mathrm{m})$.

2. Menentukan jumlah cluster (c), pangkat untuk matriks partisi (w), maksimum iterasi (MaxIter), error terkecil yang diharapkan $(\varepsilon)$, fungsi objektif awal $(\mathrm{P} 0=0)$, dan iterasi awal $(\mathrm{t}=1)$.

3. Membangkitkan bilangan random $\mu \mathrm{ik}, \mathrm{i}=1,2, \ldots, \mathrm{n} ; \mathrm{k}=1,2, \ldots, \mathrm{c}$ sebagai elemen matriks partisi awal U. Menghitung jumlah setiap kolom yang dapat dilihat dalam persamaan (1) dan (2):

$$
\mathrm{Q}_{\mathrm{i}}=\sum_{k=1}^{c} \mu_{\mathrm{i}} k
$$

dengan $\mathrm{j}=1,2, \ldots, \mathrm{n}$.

Menghitung :

$\mu_{j k}=\frac{\mu_{i k}}{Q_{i}}$ 
4. Menghitung pusat cluster ke-k: Vkj, dengan $\mathrm{k}=1,2, \ldots, \mathrm{c}$; dan $\mathrm{j}=1,2, \ldots, \mathrm{m}$, menggunakan persamaan (3) :

$$
V_{k j}=\frac{\sum_{i=1}^{n}\left(\left(\mu_{i k}\right)^{\mathrm{w}} \cdot X_{i j}\right)}{\sum_{i=1}^{n}\left(\left(\mu_{i k}\right)^{\mathrm{w}}\right.}
$$

$\mathrm{V}_{k j}=$ pusat cluster ke-k untuk atribut ke-j

$\mathrm{V}_{i k}=$ derajat keanggotaan untuk data sampel ke-i pada cluster $\mathrm{ke}-\mathrm{k}$

$\mathrm{V}_{i j=}$ data ke-i, atribut ke-j

5. Menghitung fungsi objektif pada iterasi ke-t menggunakan persamaan (4):

$$
P t=\sum_{i=1}^{n} \sum_{k=1}^{c}\left(\left[\sum_{j=1}^{m}\left(X_{i j}-V_{k j}\right)^{2}\right]\left(\mu_{i k}\right)^{\mathrm{w}}\right.
$$

dengan : $\mathrm{V}_{\mathrm{kj}}=$ pusat cluster ke-k untuk atribut ke-j

$\mu_{i k}=$ derajat keanggotaan untuk data sampel ke-i pada cluster ke-k

$\mathrm{X}_{i j}=$ data ke-i, atribut ke-j

$\mathrm{P}_{t}=$ fungsi objektif pada iterasi ke- $\mathrm{t}$

6. Menghitung perubahan matriks partisi menggunakan persamaan (5):

$$
\mu_{k j}=\frac{\left[\sum_{j=1}^{n}\left(X_{i j}-V_{k j}\right)^{2}\right] \frac{-1}{w-1}}{\sum_{i=1}^{n}\left[\sum_{j=1}^{n}\left(X_{i j}-V_{k j}\right)^{2}\right] \frac{-1}{w-1}}
$$

dengan $\mathrm{i}=1,2, \ldots, \mathrm{n} ;$ dan $\mathrm{k}=1,2, \ldots, \mathrm{c}$.

Dimana:

Vkj = pusat cluster ke-k untuk atribut ke-j

$\mathrm{X} i j=$ data ke-i, atribut ke-j

$\mu i k=$ derajat keanggotaan untuk data sampel ke-i pada cluster $\mathrm{ke}-\mathrm{k}$

7. Mengecek kondisi berhenti :

Jika : ( $|\mathrm{Pt}-P t-1|<-\varepsilon)$ atau ( $\mathrm{t}>$ Maxlter) maka berhenti. Jika tidak : $\mathrm{t}=\mathrm{t}+1$, ulangi langkah ke4

\section{METODE PENELITIAN}

Penelitian yang dilakukan berupa penelitian kuantitatif dan kualitatif, dengan tahapan penelitian sebagai berikut :

\subsection{Identifikasi masalah}

Pada tahapan penelitian ini peneliti mengangkat bagaimana cara untuk melakukan Pemetaan Wilayah Lingkungan Sehat dengan metode Fuzzy C-Menas, sehingga dapat melihat keakuratan dari metode tersebut untuk memperoleh hasil yang sesuai. Wilayah kajian dalam penelitian ini dilakukan di Kabupaten Majene. Data yang didapat dari hasil wawancara dan observasi di Dinas Kesehatan Kabupaten Majene. 


\subsection{Pengumpulan Data}

Berdasarkan hasil wawancara dan observasi yang didapat berupa data kesehatan lingkungan berdasarkan program sanitasi lingkungan yang ada di Dinas Kesehatan Majene pada tahun 2016.

\subsection{Praproses Data}

Dalam praproses data dilakukan proses data reduction atau proses merubah data yang berskala besar menjadi lebih kecil, dengan pengurangan atribut dan data, namun tetap menghasilkan analitis yang sama. Proses data ini menghasilkan data dari 8 kecamatan di Kabupaten Majene yang siap diolah. Dari hasil ini penulis menggunakan data berdasarkan parameter yang akan digunakan yaitu : rumah, jamban, penyedian air bersih, pembuangan kotoran dan sarana pengolahan air limbah (SPAL).

\subsection{Clustering dengan Fuzzy C-means}

Pada tahap ini siapkan data sesuai parameter yang ditentukan, kemudian diolah dan di bagi menjadi 2 kategori klaster yaitu sehat dan tidak sehat berdasarkan 5 parameter yang akan di gunakan yaitu : rumah, jamban, penyedian air bersih, pembuangan kotoran dan sarana pengolahan air limbah (SPAL) di 8 kecamatan yang ada di Kabupaten Majene.

\subsection{Analisis Cluster}

Pada Proses analisis cluster dilakukan untuk melihat kesesuaian dalam proses Pemetaan dengan algoritma Fuzzy C-Means, jika hasil yang di dapat belum sesuai makan akan kembali ke proses Clustering dengan Fuzzy C-menas, tetapi jika sudah sesuai maka hasil sudah bisa di dapatkan, berupa kelompok-kelompok wilayah yang memiliki tingkat kemiripan yang sama.

\section{HASIL DAN PEMBAHASAN}

Proses clustering wilayah lingkungan sehat menggunakan data yang ada di Dinas Kesehatan Kabupaten Majene bagian sanitasi lingkungan. Data yang diuji berdasarkan 8 kecamatan dengan 11 puskesmas yang ad di kabupaten Majene dan terdiri dari 5 parameter yaitu, jumlah rumah sehat, jumlah jamban, jumlah penyedia air bersih, jumlah tempat sampah dan jumlah sarana pembuangan air limbah dapat dilihat pada tabel 1.

Proses clustering menggunakan algoritma FCM. Proses clustering dilakukan dengan menetapkan nilai awal sebagai berikut :
a. Jumlah cluster (c)
: 2 (cluster)
b. Pangkat (w)
c. Maksimum iterasi (MaxIter)
: 100 (MaxIter)
d. Error terkecil yang diharapkan $(\dot{\varepsilon}) \quad: 10^{-5}(\dot{\varepsilon})$
e. Fungsi objektif awal (P0) $\quad: 0(\mathrm{P} 0)$
f. Iterasi awal (t)

Langkah pertama perhitungan Fuzzy C-Means yaitu menentukan derajat keanggotaan melalui matrik partisi U yang dibentuk secara random. Data yang di peroleh dari Dinas Kesehatan Majene berupa angka jumlah dari setiap parameter. Sehingga didapatkan Keanggotan Cluster $(\mu)$ Posisi dan nilai matrikx dibangun secara random. Dimana nilai keanggtotaan terletak pada interval 0 sampai dengan 1. Dengan syarat jumlah nilai keanggotaan suatu data semua cluster harus sama dengan 1. Matrik partisi $(\mu)$ dapat dilihat pada Tabel 1.

Selanjutnya menentukan Pusat Cluster (V). Pada iterasi pertama, dengan menggunakan persamaan 3. Dapat dihitung 2 pusat cluster. Cara pertama dilakukan pengkuadratan pada derajat keanggotaan pertama sehingga didapatkan 0,36 pada nilai derajat keanggotaan untuk bilangan nialai Random U pada cluster pertama. Selanjutnya nilai Xi1-Xi5 merupakan data hasil inisialisai dari 5 parameter yang digunakan. Kemudian untuk mendapatkan hasil derajat ke anggotaan $\left(\mu_{i 1}\right)^{2}$ dari data Xi1 dilakuakan perkalian dari nilai data Xi1 dan hasil pengkuadratan nilai random U sehingga di dapatkan 873,72. Untuk lebih jelasnya dapat di lihat pada Tabel 2. 
Tabel 1. Bilangan Random U

\begin{tabular}{llccccccc}
\hline & & \multicolumn{4}{c}{ Alternatif Kriteria $\left(\mathrm{X}_{\mathrm{ij}}\right)$} & \multicolumn{3}{c}{$\begin{array}{c}\text { Keanggotaan } \\
\text { Noster }(\mu)\end{array}$} \\
\cline { 3 - 9 } No & Puskesmas & Rumah & Jamban & $\begin{array}{c}\text { Air } \\
\text { Bersih }\end{array}$ & $\begin{array}{c}\text { Tempat } \\
\text { Sampah }\end{array}$ & SPAL & C1 & C2 \\
& & & & & & & & \\
\hline 1 & Banggae I & 2.427 & 2.501 & 2.743 & 3.487 & 3.355 & 0,6 & 0,4 \\
2 & Totoli & 1.679 & 2.282 & 1.074 & 2.312 & 2.878 & 0,5 & 0,5 \\
3 & Banggae II & 2.446 & 2.305 & 580 & 2.250 & 2.169 & 0,7 & 0,3 \\
4 & Lembang & 3.442 & 2.587 & 1.350 & 2.881 & 2.881 & 0,8 & 0,2 \\
5 & Pamboang & 2.872 & 3.138 & 1.165 & 3.759 & 3.665 & 0,6 & 0,4 \\
6 & Sendana I & 2.435 & 4.030 & 3.593 & 4.316 & 4.316 & 0,6 & 0,4 \\
7 & Tammerodo & 2.008 & 355 & 960 & 1.798 & 1.755 & 0,4 & 0,6 \\
8 & Sendana II & 1.187 & 1.068 & 1.193 & 1.274 & 1.343 & 0,5 & 0,5 \\
9 & Salutambung & 473 & 572 & 116 & 395 & 440 & 0,3 & 0,7 \\
10 & Ulumanda & 660 & 542 & 62 & 150 & 318 & 0,2 & 0,8 \\
11 & Malunda & 2.227 & 1.737 & 1.168 & 3.033 & 2.111 & 0,6 & 0,4 \\
\hline
\end{tabular}

Tabel 2. Perhitungan Cluster pada Iterasi Pertama Cluster ke-1

\begin{tabular}{|c|c|c|c|c|c|c|c|c|c|c|c|}
\hline \multirow{2}{*}{$\begin{array}{c}\text { Derajat } \\
\text { Keanggotaan } \\
\text { Pada Cluster } \\
\text { Ke-1 }\end{array}$} & \multicolumn{5}{|c|}{ Data yang diCluster } & \multirow{2}{*}{$\left(\mu_{i 1}\right)^{2}$} & \multirow{2}{*}{$\underset{* X_{i 1}}{\left(\mu_{i 1}\right)^{2}}$} & \multirow{2}{*}{$\underset{* X_{i 2}}{\left(\mu_{i 1}\right)^{2}}$} & \multirow{2}{*}{$\frac{\left(\mu_{i 1}\right)^{2 *}}{X_{i 3}}$} & \multirow{2}{*}{$\frac{\left(\mu_{i 1}\right)^{2 *}}{X_{i 4}}$} & \multirow{2}{*}{$\frac{\left(\mu_{i 1}\right)^{2 *}}{X_{i 5}}$} \\
\hline & Xi1 & $\mathrm{Xi2}$ & $\mathrm{Xi3}$ & $\mathrm{Xi4}$ & Xi5 & & & & & & \\
\hline 0,6 & $\begin{array}{l}2.4 \\
27\end{array}$ & 2.501 & 2.743 & 3.487 & 3.355 & 0,36 & 873,72 & 900,36 & 987,48 & 1255,32 & 1207,80 \\
\hline 0,5 & $\begin{array}{l}1.6 \\
79\end{array}$ & 2.282 & 1.074 & 2.312 & 2.878 & 0,25 & 419,75 & 570,50 & 268,50 & 578,00 & 719,50 \\
\hline 0,7 & $\begin{array}{c}2.4 \\
46\end{array}$ & 2.305 & 580 & 2.250 & 2.169 & 0,49 & 1198,54 & $\begin{array}{c}1129,4 \\
5\end{array}$ & 284,20 & 1102,50 & 1062,81 \\
\hline 0,8 & $\begin{array}{l}3.4 \\
42\end{array}$ & 2.587 & 1.350 & 2.881 & 2.881 & 0,64 & 2202,88 & $\begin{array}{c}1655,6 \\
8\end{array}$ & 864,00 & 1843,84 & 1843,84 \\
\hline 0,6 & $\begin{array}{l}2.8 \\
72\end{array}$ & 3.138 & 1.165 & 3.759 & 3.665 & 0,36 & 1033,92 & $\begin{array}{c}1129,6 \\
8\end{array}$ & 419,40 & 1353,24 & 1319,40 \\
\hline 0,6 & $\begin{array}{c}2.4 \\
35\end{array}$ & 4.030 & 3.593 & 4.316 & 4.316 & 0,36 & 876,60 & $\begin{array}{c}1450,8 \\
0\end{array}$ & 1293,48 & 1553,76 & 1553,76 \\
\hline 0,4 & $\begin{array}{l}2.0 \\
08\end{array}$ & 355 & 960 & 1.798 & 1.755 & 0,16 & 321,28 & 56,80 & 153,60 & 287,68 & 280,80 \\
\hline 0,5 & $\begin{array}{l}1.1 \\
87\end{array}$ & 1.068 & 1.193 & 1.274 & 1.343 & 0,25 & 296,75 & 267,00 & 298,25 & 318,50 & 335,75 \\
\hline 0,3 & $\begin{array}{c}47 \\
3\end{array}$ & 572 & 116 & 395 & 440 & 0,09 & 42,57 & 51,48 & 10,44 & 35,55 & 39,60 \\
\hline 0,2 & $\begin{array}{c}66 \\
0\end{array}$ & 542 & 62 & 150 & 318 & 0,04 & 26,40 & 21,68 & 2,48 & 6,00 & 12,72 \\
\hline \multirow[t]{3}{*}{0,6} & $\begin{array}{l}2.2 \\
27\end{array}$ & 1.737 & 1.168 & 3.033 & 2.111 & 0,36 & 801,72 & 625,32 & 420,48 & 1091,88 & 759,96 \\
\hline & & & & & $\sum$ & 3,36 & 8094,13 & 7858,8 & 5002,3 & 9426,27 & 9135,94 \\
\hline & & & & \multicolumn{3}{|c|}{$\sum\left[\left(\mu_{i 1}^{2}\right)^{*} X_{i j}\right] / \sum\left(\mu_{i 1}{ }^{2}\right)$} & 2408,97 & 2338,9 & 1488,8 & 2805,44 & 2719,03 \\
\hline
\end{tabular}


Untuk perhitungan cluster kedua juga dilakuakan hal sama seperti perhitungan di cluster pertama hasilnya dapat dilihat pada Tabel 3.

Tabel 3. Perhitungan Cluster pada Iterasi Pertama Cluster ke-2

\begin{tabular}{|c|c|c|c|c|c|c|c|c|c|c|c|}
\hline \multirow{2}{*}{$\begin{array}{c}\text { Derajat } \\
\text { Keanggot } \\
\text { aan Pada } \\
\text { Cluster } \\
\text { Ke-1 }\end{array}$} & \multicolumn{5}{|c|}{ Data yang diCluster } & \multirow{2}{*}{$\left(\mu_{i 1}\right)^{2}$} & \multirow{2}{*}{$\begin{array}{c}\left(\mu_{\mathrm{i} 1}\right)^{2 *} \\
\mathrm{X}_{\mathrm{i} 1}\end{array}$} & \multirow{2}{*}{$\begin{array}{c}\left(\mu_{\mathrm{i} 1}\right)^{2 *} \\
\mathrm{X}_{\mathrm{i} 2}\end{array}$} & \multirow{2}{*}{$\begin{array}{c}\left(\mu_{\mathrm{i} 1}\right)^{2 *} \\
\mathrm{X}_{\mathrm{i} 3}\end{array}$} & \multirow{2}{*}{$\begin{array}{c}\left(\mu_{\mathrm{i} 1}\right)^{2 *} \\
\mathrm{X}_{\mathrm{i} 4}\end{array}$} & \multirow{2}{*}{$\begin{array}{c}\left(\mu_{i 1}\right)^{2 *} \\
X_{i 5}\end{array}$} \\
\hline & Xi1 & $\mathrm{xi2}$ & Xi3 & $\mathrm{Xi4}$ & Xi5 & & & & & & \\
\hline 0,4 & 2.427 & 2.501 & 2.743 & 3.487 & 3.355 & 0,160 & 388,320 & 400,160 & 438,880 & 557,920 & 536,800 \\
\hline 0,5 & 1.679 & 2.282 & 1.074 & 2.312 & 2.878 & 0,250 & 419,750 & 570,500 & 268,500 & 578,000 & 719,500 \\
\hline 0,3 & 2.446 & 2.305 & 580 & 2.250 & 2.169 & 0,090 & 220,140 & 207,450 & 52,200 & 202,500 & 195,210 \\
\hline 0,2 & 3.442 & 2.587 & 1.350 & 2.881 & 2.881 & 0,040 & 137,680 & 103,480 & 54,000 & 115,240 & 115,240 \\
\hline 0,4 & 2.872 & 3.138 & 1.165 & 3.759 & 3.665 & 0,160 & 459,520 & 502,080 & 186,400 & 601,440 & 586,400 \\
\hline 0,4 & 2.435 & 4.030 & 3.593 & 4.316 & 4.316 & 0,160 & 389,600 & 644,800 & 574,880 & 690,560 & 690,560 \\
\hline 0,6 & 2.008 & 355 & 960 & 1.798 & 1.755 & 0,360 & 722,880 & 127,800 & 345,600 & 647,280 & 631,800 \\
\hline 0,5 & 1.187 & 1.068 & 1.193 & 1.274 & 1.343 & 0,250 & 296,750 & 267,000 & 298,250 & 318,500 & 335,750 \\
\hline 0,7 & 473 & 572 & 116 & 395 & 440 & 0,490 & 231,770 & 280,280 & 56,840 & 193,550 & 215,600 \\
\hline 0,8 & 660 & 542 & 62 & 150 & 318 & 0,640 & 422,400 & 346,880 & 39,680 & 96,000 & 203,520 \\
\hline \multirow[t]{3}{*}{0,4} & 2.227 & 1.737 & 1.168 & 3.033 & 2.111 & 0,160 & 356,320 & 277,920 & 186,880 & 485,280 & 337,760 \\
\hline & & & & & $\sum$ & 2,76 & 4045,13 & 3728,35 & 2502,11 & 4486,27 & 4568,14 \\
\hline & & & & \multicolumn{4}{|c|}{$\sum\left[\left(\mu_{\mathrm{i} 1}{ }^{2}\right)^{*} X_{\mathrm{i}}\right] / \sum\left(\mu_{\mathrm{i} 1}{ }^{2}\right)$} & $\begin{array}{c}1465,626 \\
812\end{array}$ & $\begin{array}{c}1350,851 \\
449\end{array}$ & $\begin{array}{c}906,5615 \\
942\end{array}$ & $\begin{array}{c}1625,460 \\
145\end{array}$ \\
\hline
\end{tabular}

Dari perhitungan cluster didapatkan nilai pusat cluster V hasil Pusat Cluster V diperoleh dengan cara membagi hasil jumlah keseluruhan dari nilai kuadrat random $U$ dengan hasil jumlah keseluruhan tiap data pada $\left(\mu_{i 1}\right)^{2}$ atau nilai derajat keanggotaan setiap parameter. Sehingga didapatkan hasil Pusat Culster V untuk iterasi pertama seperti yang tertera pada Tabel 4.

Tabel 4. Hasil Pusat Cluster (V)

\begin{tabular}{rrrrr}
\hline \multicolumn{5}{c}{ HASIL PUSAT CLUSTER (V) } \\
\hline 2408,967 & 2338,914 & 1488,783 & 2805,438 & 2719,03 \\
1465,627 & 1350,851 & 906,5616 & 1625,46 & 1655,123 \\
\hline
\end{tabular}

Selanjutnya menghitung fungsi obyektif $(\mathrm{Pt})$. Fungsi objektif pada iterasi pertama P1 dihitung dengan menggunakan persamaan $4, \mathrm{P} 1=31412426,82$. Perhitungan Fungsi objektif pada iterasi pertama dengan cara nilai variabel Fuzzy $\mathrm{X}_{\mathrm{ij}}$ dikurang dengan pusat cluster $\mathrm{v}_{\mathrm{k}}$, kemudian hasil pengurangannya di kuadratkan lalu masing masing hasil kuadrat di jumlahkan untuk dikalikan dengan kuadrat dari derajat keanggotaan Uik untuk tiap cluster. Setelah itu jumlahkan semua cluster untuk mendapatkan fungsi objektif pt. Hasil perhitungan Fungsi objektif dapat di lihat pada Tabel 5.

Langkah selanjutnya menghitung Perubahan Matriks Partisi (U). Perubahan matriks partisi (U) dihitung menggunakan persamaan 5. Untuk mencari perubahan matrix partisi uik pengurangan nilai variabel fuzzy $\mathrm{X}_{\mathrm{ij}}$ dilakukan kembali terhadap pusat cluster $\mathrm{V}_{\mathrm{kj}}$, lalu dikuadratkan. Kemudian dijumlahkan lalu dipangkatkan dengan -1. Setelah itu normalisasikan semua data derajat keanggotaan baru dengan cara menjumlahkan derajat keanggotaan baru. Hasilnaya kemudian dibagi 
dengan derajat keanggotaan yang baru. Proses ini dilakukan agara derajat keanggotaan yang baru mempunyai rentang antara 0 dan tidak lebih dari 1 . Hasil Perhitungan secara rinci dapat dilihat pada Tabel 6.

Tabel 5. Hasil Perhitungan Fungsi Objektif pada Iterasi Pertama

\begin{tabular}{|c|c|c|c|c|}
\hline \multicolumn{2}{|c|}{$\begin{array}{c}\text { Kuadrat Derajat } \\
\text { Keanggotaan data ke-i }\end{array}$} & {$\left[\sum_{j i \alpha}^{6}\left(X_{i j}-V_{i j}\right)^{2}\right]^{2}\left(\mu_{i}\right)^{2}$} & {$\left[\sum_{j=1}^{6}\left(X_{j}-V_{2 j}\right)^{2}\right]^{\prime}\left(\mu_{i 2}\right)^{2}$} & \multirow[t]{2}{*}{$\mathrm{L} 1+\mathrm{L} 2$} \\
\hline$\mu_{i 1}{ }^{2}$ & $\mu_{\mathrm{i} 2}{ }^{2}$ & L1 & $\mathrm{L} 2$ & \\
\hline 0,36 & 0,16 & 888711,724 & 1915919,67 & 2804631,4 \\
\hline 0,25 & 0,25 & 244222,049 & 726841,507 & 971063,56 \\
\hline 0,49 & 0,09 & 705331,079 & 236906,364 & 942237,44 \\
\hline 0,64 & 0,04 & 755141,218 & 348396,245 & 1103537,5 \\
\hline 0,36 & 0,16 & 994289,271 & 2212827,68 & 3207117 \\
\hline 0,36 & 0,16 & 4363305,81 & 4744598,84 & 9107904,6 \\
\hline 0,16 & 0,36 & 1011293,31 & 478256,338 & 1489549,6 \\
\hline 0,25 & 0,25 & 1858667,94 & 115157,48 & 1973825,4 \\
\hline 0,09 & 0,49 & 1778280,41 & 2551656,25 & 4329936,7 \\
\hline 0,04 & 0,64 & 845591,46 & 3828121,97 & 4673713,4 \\
\hline \multirow[t]{2}{*}{0,36} & \multirow[t]{2}{*}{0,16} & \multirow[t]{2}{*}{331127,504} & 477782,718 & 808910,22 \\
\hline & & & Fungsi Objective $=\sum$ & 31412427 \\
\hline
\end{tabular}

Mengecek kondisi Berhenti. Karena $|\mathrm{P} 1-\mathrm{P} 0|=|31412426,82-0|=31412426,82$ $\dot{\varepsilon}\left(10^{-5}\right)$, dan iterasi $=1<$ Maxiter $(=100)$, maka proses di lanjutkan ke iterasi ke-dua $(\mathrm{t}=2)$. Pada iterasi kedua ditentukan kembali 2 pusat cluster Vkj seperti langkah pehitungan pertama dan hasilnya ditunjukkan pada tabel 7.

Tabel 6. Hasil Perhitungan Derajat Keanggotaan Baru

\begin{tabular}{ccr}
\hline$\left[\sum_{j=1}^{6}\left(X_{i j}-V_{1 j}\right)^{2}\right]$ & {$\left[\sum_{j=1}^{6}\left(x_{i j}-V_{2 j}\right)^{2}\right]$} & $\sum_{k=1}^{3}\left[\sum_{j=1}^{6}\left(x_{i j}-V_{i j}\right)^{2}\right]^{-1}$ \\
\hline 1 & L2 & \multicolumn{1}{c}{$\mathrm{LT}=\mathrm{L} 1+\mathrm{L} 2$} \\
\hline $4,05081 \mathrm{E}-07$ & $8,35108 \mathrm{E}-08$ & $4,88592 \mathrm{E}-07$ \\
$1,02366 \mathrm{E}-06$ & $3,43954 \mathrm{E}-07$ & $1,36761 \mathrm{E}-06$ \\
$6,94709 \mathrm{E}-07$ & $3,79897 \mathrm{E}-07$ & $1,07461 \mathrm{E}-06$ \\
$8,47524 \mathrm{E}-07$ & $1,14812 \mathrm{E}-07$ & $9,62335 \mathrm{E}-07$ \\
$3,62068 \mathrm{E}-07$ & $7,23057 \mathrm{E}-08$ & $4,34373 \mathrm{E}-07$ \\
$8,25063 \mathrm{E}-08$ & $3,37226 \mathrm{E}-08$ & $1,16229 \mathrm{E}-07$ \\
$1,58213 \mathrm{E}-07$ & $7,52734 \mathrm{E}-07$ & $9,10948 \mathrm{E}-07$ \\
$1,34505 \mathrm{E}-07$ & $2,17094 \mathrm{E}-06$ & $2,30545 \mathrm{E}-06$ \\
$5,06107 \mathrm{E}-08$ & $1,92032 \mathrm{E}-07$ & $2,42643 \mathrm{E}-07$ \\
$4,73042 \mathrm{E}-08$ & $1,67184 \mathrm{E}-07$ & $2,14488 \mathrm{E}-07$ \\
$1,08719 \mathrm{E}-06$ & $3,3488 \mathrm{E}-07$ & $1,42207 \mathrm{E}-06$ \\
\hline
\end{tabular}

Tabel 7. Hasil Pusat Cluster V pada iterasi ke 2

\begin{tabular}{lllll}
\hline \multicolumn{5}{c}{ Hasil Pusat Kluster V } \\
\hline 2515 & 2588,30387 & 1636,84084 & 3105,5672 & 3013,013 \\
1268 & 918,611489 & 769,087151 & 1218,4123 & 1259,058 \\
\hline
\end{tabular}


Fungsi Objektif pada iterasi kedua (P2) juga di hitung seperti perhitungan fungsi objekif pada iterasi pertama, hasilnya adalah $:=|23671869,06|$ Karena $|\mathrm{P} 2-\mathrm{P} 1|=\mid 23671869,06-31412426,82$ $\mid=7740557,767$. Hasil perbaikan matriks partisi untuk iterasi ke dua (U2) :

Tabel 8. Hasil Perhitungan Derajat Keanggotaan Baru (Matriks Partisi)

\begin{tabular}{rcr}
\hline$\left[\sum_{j=1}^{6}\left(X_{i j}-V_{1 j}\right)^{2}\right]$ & {$\left[\sum_{j=1}^{6}\left(x_{i j}-V_{2 j}\right)^{2}\right]$} & $\sum_{i=1}^{3}\left[\sum_{j=1}^{6}\left(x_{i j}-V_{i j}\right)^{2}\right]^{-1}$ \\
\hline \multicolumn{1}{c}{$\mathrm{L} 1$} & \multicolumn{1}{c}{$\mathrm{L} 2$} & $\mathrm{LT}=\mathrm{L} 1+\mathrm{L} 2$ \\
\hline $6,66012 \mathrm{E}-07$ & $5,78602 \mathrm{E}-08$ & $7,23872 \mathrm{E}-07$ \\
$5,68768 \mathrm{E}-07$ & $1,68417 \mathrm{E}-07$ & $7,37186 \mathrm{E}-07$ \\
$3,7788 \mathrm{E}-07$ & $1,90924 \mathrm{E}-07$ & $5,68804 \mathrm{E}-07$ \\
$9,91385 \mathrm{E}-07$ & $7,55165 \mathrm{E}-08$ & $1,0669 \mathrm{E}-06$ \\
$6,64889 \mathrm{E}-07$ & $5,02553 \mathrm{E}-08$ & $7,15144 \mathrm{E}-07$ \\
$1,102 \mathrm{E}-07$ & $2,63456 \mathrm{E}-08$ & $1,36545 \mathrm{E}-07$ \\
$1,11166 \mathrm{E}-07$ & $6,74044 \mathrm{E}-07$ & $7,85209 \mathrm{E}-07$ \\
$9,60006 \mathrm{E}-08$ & $4,57213 \mathrm{E}-06$ & $4,66813 \mathrm{E}-06$ \\
$4,07872 \mathrm{E}-08$ & $3,95639 \mathrm{E}-07$ & $4,36427 \mathrm{E}-07$ \\
$3,83016 \mathrm{E}-08$ & $3,29102 \mathrm{E}-07$ & $3,67404 \mathrm{E}-07$ \\
$5,41533 \mathrm{E}-07$ & $1,73397 \mathrm{E}-07$ & $7,1493 \mathrm{E}-07$ \\
\hline
\end{tabular}

$\grave{\varepsilon}\left(10^{-5}\right)$, dan iterasi $=1<$ Maxiter $(=100)$, maka proses di lanjutkan ke iterasi ke-dua $(\mathrm{t}=3)$. Demikian Hingga Seterusnya hingga $\left|\mathrm{P}_{\mathrm{t}}-\mathrm{P}_{\mathrm{t}-1}\right|<\dot{\varepsilon}$, atau $\mathrm{t}>$ MaxIter. Pada kasus ini hasil perhitungan iterasi berhenti pada iterasi ke 70. Untuk mendapatkan hasil Derajat keanggotaan data pada cluster 1 dan 2 dilakukan dengan cara membagi tiap cluster dengan jumlah keseluruhan cluster dari derajat keanggotaan baru matriks partisi proses ini dapat dihitung dengan Ms.Excel. Hasilnya diperoleh dari perhitungan 11 Puskesmas yang ada di Kabupaten Majene, yaitu : Cluster 1 terdiri dari 7 wilayah dan cluster 2 terdiri dari 4 wilayah. Untuk lebih jelasnya dapat dilihat pada tabel 9.

\begin{tabular}{ccccc} 
Tabel 9. Hasil Perhitungan & & \\
Data Ke & $\begin{array}{c}\text { Derajat keanggotan }(\mathrm{m}) \\
\text { data pada Cluster ke- }\end{array}$ & \multicolumn{2}{c}{ Cluster } \\
\cline { 2 - 5 } & $\mu_{1}$ & $\mu_{2}$ & 1 & 2 \\
\hline 1 & 0,945711 & 0,05429 & $\mathrm{x}$ & \\
2 & 0,649955 & 0,35005 & $\mathrm{x}$ & \\
3 & 0,517259 & 0,48274 & $\mathrm{x}$ & \\
4 & 0,902147 & 0,09785 & $\mathrm{x}$ & \\
5 & 0,945478 & 0,05452 & $\mathrm{x}$ & \\
6 & 0,843356 & 0,15664 & $\mathrm{x}$ & \\
7 & 0,098249 & 0,90175 & & $\mathrm{x}$ \\
8 & 0,020936 & 0,97906 & & $\mathrm{x}$ \\
9 & 0,095008 & 0,90499 & & $\mathrm{x}$ \\
10 & 0,105024 & 0,89498 & & $\mathrm{x}$ \\
11 & 0,616549 & 0,38345 & $\mathrm{x}$ & \\
\hline
\end{tabular}




\section{KESIMPULAN DAN SARAN}

\subsection{Kesimpulan}

Berdasarkan hasil penelitian pada bab sebelumya dapat ditarik kesimpulan bahwa dengan menggunakan metode Fuzzy C-Means dapat diketahui pemetaan wilayah lingkungan sehat berdasarkan 5 parameter yakni, Rumah, Jamban, Sarana Air Bersih, Tempat sampah dan SPAL, dengan jumlah data sebanyak 11 puskesmas di Kabupaten Majene. Didapatkan hasil clustering yaitu; Cluster 1 Kecamatan Banggae, Banggae Timur, Pamboang, Sendana 1 dan Malunda, dan kategori Cluster 2 yaitu Kecamatan Tamero'do, Tubo Sendana, Salutambung dan Ulumanda. Hasil cluster tersebut di dapatkan berdasrakn hasil derajat keanggotaan yang terbentuk. Jika hasil derajat keanggotaan lebih tinggi maka akan masuk dalam cluster 1 dan jika derajat keangootaan cenderung lebih rendah maka akan masuk dalam kategori cluster 2 .

\subsection{Saran}

Adapun saran yang ingin penulis sampaikan adalah sebagai berikut :

1. Penelitian ini dibuat sesuai dengan kebutuhan dalam pemetaan wilayah lingkungan sehat di lingkup Kecamatan, diharapkan penelitian selanjutnya dapat menangani ukuran atau jumlah yang besar sehingga dapat diterapkan di lingkup yang lebih besar seperti kantor kabupaten dan sejajarnya.

2. Di penelitian selanjutnya bisa di tambahkan lebih banyak parameter dan indikator yang digunakan agar hasil clustering yang dihasilkan lebih akurat.

\section{REFERENSI}

[1] B. P. S. K. Majene, “Majene Dalam Angka , BPS,” 2016.

[2] F. M. H. \&. A. H. A. Febrianti, " Perbandingan Pengklusteran Data Iris Menggunakan Metode K-Means Dan Fuzzy C-Means,” Jurnal Matematika”MANTIK”, 2016.

[3] A. Z. E. M. Ramadhan, "Perbandingan K-Means dan Fuzzy C-Means untk Pengelompokan Data User Knowledge Modeling,” 2017.

[4] S. \&. P. H. Kusumadewi, "Aplikasi Logika Fuzzy Untuk Pendukung Keputusan,” Yogyakarta: Graha Ilmu, 2010.

[5] A. P. \&. R. K. Pertiwi, "Pengelompokan Daerah Rawan Bencana Banjir Di Indonesia Tahun 2013 Menggunakan Fuzzy C-Means," Prosiding SNM, 2017.

[6] A. K. Wijaya, "Data Mining dengan Algoritma Fuzzy C-Means Studi Kasus Penjualan di UD Subur Baru," Fasilkom Udinus, 2014.

[7] A. H. Setianingrum, "Model Pemetaan Evaluasi Penilaiaan Kualifikasi Lulusan Berbasis Metode Fuzzy C-Means Clustering," Jurnal Tehnik Informatika, 2014. 
[8] T. V. K. R. J. Martin J. Bunch, "Using Geographic Information System (GIS) For Spatial Planing and Environmental Management India," International Journal of Applied Science and Tecnology, 2012.

[9] T. M. C. X. X. W. T. S. M. Z. Yinghua Lu, "Implementation Of The Fuzzy C-Means Clustering Algorithm in Meteorologi Data," International Journal of Database Theory and Application, 2013.

[10] N. I. \&. M. Selviana, “ Analisis Perbandingan K-Means dan Fuzzy C-Means untuk Pemetaan Motivasi Belajar Mahasiswa,” SNTIKI, 2016.

[11] Mukidin, "Clustering Tingkat Kesehatan Lingkungan Berdasarkan Data Penyehatan Lingkungan Pemukiman Menggunakan Metode Fuzzy C - Means (Studi Kasus : Dinas Kesehatan Kab. Cirebon). Syntax Literate," Jurnal Ilmiah Indonesia, 2019. 